\title{
Local Wisdom of Capital in Development in Aceh Besar Regency
}

\author{
Helmi Satria ${ }^{1}$, Efi Safira ${ }^{2}$ \\ 1,2 Akademi Maritim Aceh Darussalam, Indonesia \\ Olliahr1311@gmail.com,evisafira2017@gmail.com
}

\begin{abstract}
Development using a centralized approach without developing community self-reliance today is unable to solve various social problems due to the lack of developing community presence in development activities. Community development will be effective when local wisdom is used as capital by utilizing existing organizations or habits at the local level. In this case, the government as the party that provides encouragement and assistance in implementing development is enough to act as a facilitator and motivator. Let the community formulate and implement the types of development activities and how to implement them. Based on this description, the objectives of this research are as follows: (1) To describe local wisdom as development capital in the study of social reality in Aceh Besar Regency. (2) To analyze the forms of local wisdom used in development in Aceh Besar Regency. This study uses a qualitative approach in describing local wisdom as development capital with data collection techniques that the researchers did through observation, in-depth interviews and documentation. The research informants were determined by purposive sampling with consideration of their experiences in social life and their personalities. The results of the study indicate that the high level of local wisdom possessed by the people of Aceh Besar Regency is caused by a strong social base, as well as the historical orientation and dimension of the formation of social values and norms in social life due to the similarity of religion and kinship relations, so that it has an impact on implementation. development. Local wisdom that supports development in the form of agreements, cooperation, participation that is used as a habit can produce high cohesiveness in the people of Aceh Besar, and there is a passion for charity in carrying out development as well as a sense of volunteerism that evokes self-reliance as well as a strong sense of social solidarity in society. Local wisdom possessed by members of the Aceh Besar Regency community is used as capital in development in the form of trust, social networks and social norms that are still strong enough to support the realization of development in accordance with community expectations.
\end{abstract}

Keywords

Local wisdom; capital; development

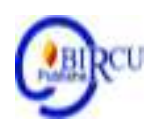

\section{Introduction}

The implementation of development in Indonesia using a centralized approach has not been able to solve social problems. Development activities do not develop capital in the form of local community self-reliance because they do not develop community participation in development activities. Whereas development will be effective if it is carried out by utilizing existing organizations at the local level, while the government only acts as a facilitator and motivator by prioritizing community involvement from planning to implementation as well as reporting and overall evaluation of development programs. 
Along with the enactment of Law No Number 9 of 2015 concerning Regional Governments and Government Regulations Number 47 of 2015 concerning Implementing Regulations of Law Number 6 of 2014 concerning Villages then can be both capital and spirit for the community to organize and manage their own household. The regulation provides an opportunity for regions to create independence in the context of developing their regions based on the principles of democracy, participation, equity, justice by taking into account the potential and diversity to optimize the use of local resources, so that local institutions have the potential to generate self-regulation capabilities.

In connection with the opportunities provided by the Act, the community can play a role in determining identity, especially with regard to strengthening the role of the community or placing the community as implementers and involved in the decisionmaking process in development. Then strengthening the spirit of good governance based on transparency, accountability, increasing professionalism, caring for the people, and high moral commitment in the development process.

Implementation of development more prioritizing the involvement of all stakeholders by prioritizing local wisdom. The people of Aceh Besar Regency have quite a lot of capital in the form of social values such as the culture of mutual cooperation, and various other forms of local wisdom. Local culture strong in The people of Aceh Besar Regency are caused by the historical orientation and dimension of the formation of values and norms, because of the similarity of religion and kinship relations. The implementation of local wisdom-based development in development is not only physical, but also non-physical. With regard to development, various efforts are continuously carried out in stages, namely through capacity building of government apparatus, institutional capacity building, community training, traditional and socio-cultural empowerment, construction of physical facilities and improvement of family economic business in order to increase income and community welfare. Based on the description of the background above, this research seeks to raise the phenomenon of development based on local wisdom with the focus of research directed at providing an overview of the importance of using local wisdom in development.

\section{Review of Literature}

\subsection{Local Wisdom Theory}

Local wisdom is a local cultural wealth related to the way of life that also accommodates policies based on traditions that apply to an area, so that local wisdom is not only in the form of cultural norms and values, but also all elements of ideas, including those that have implications for technology, health management, development and aesthetics. With this understanding, what is included as the elaboration of local wisdom, in addition to proverbs and all other linguistic expressions are also various patterns of action and the results of material culture.

Local wisdom consists of two syllables, namely wisdom and local. The word Wisdom etymologically means a person's ability to use his mind to respond to an event, object or situation. While local shows the interaction space where the event or situation occurs. Thus, local wisdom is substantially the prevailing norm in a society that is believed to be true and becomes a reference in acting and behaving daily. Therefore, local wisdom is an entity that greatly determines human dignity in the community.

Gobyah (2003) defines local wisdom as "truth that has been a tradition in an area". Meanwhile, Ridwan (2007) defines local wisdom or often referred to as local wisdom as "human effort by using his mind to act and behave towards an object or event that occurs 
in a certain space". By seeing local wisdom as a form of culture, it will experience continuous reinforcement so that it becomes better. Local wisdom is a cultural manifestation that occurs with reinforcements in life as well as being able to show it as a form of human humanization in culture.

Tradition is something that is passed down from the heritage of the ancestors to the next generation in a relay descends performed by the indigenous communities that have become deeply entrenched the culture in life. (Purba, N. 2020)

In Acehnese society, tradition is a local wisdom that needs to be preserved, preserved, and applied as part of the norms of life. The high customary values in Acehnese society are reflected in the implementation of development and also in farming activities. For example, in clearing land for farming, in Aceh there are a number of rules that have existed and developed since ancient times.

Values in local communities as glue are driven by various factors. In general, the factors that encourage the occurrence of local communities according to Ngarawula (2012: 33) come from within each individual himself through:

1) Social desire, namely there is an urge to group each individual.

2) The desire to imitate, the desire to know secretly or frankly some of the symptoms of one's actions, for example imitating the work of parents or other people.

3) The desire to fight, that is, there is competition in it.

4) The desire to associate, namely the spirit to join certain people in certain groups.

5) The desire to tell, namely the desire to convey feelings to others which is usually conveyed by voice, or by other actions.

6) There is a desire for freedom, namely the desire to escape from restraint.

\subsection{Capital Concept}

Since the first study of social capital was conducted in early 1916 by Lyda Judson Hanifan until the birth of the modern study of social capital in the late 20th century, which was pioneered by Putnam, Coleman, and Fukuyama, there have been many definitions given by experts regarding social capital. In general, there are four main streams (play streams) theory of social capital, including the first theory of social capital Bourdieu, second theory of social capital Coleman, third theory of social capital Putnam and Fukuyama and four other formulations of various figures. Of the four main streams, the third theory is the most dominating in various studies in the West.

Bourdieu (1986) explains that "social capital is potential or actual sources in the form of quality relationships between community members, which gives each member means and capital support for mutual benefit". Furthermore, Bourdieu stated that there are three kinds of capital, namely "money capital, social capital, and cultural capital, and it will be used more effectively if there is social interaction or social relations among the three".

From Bourdieu's opinion above, the terminology of capital has three forms, namely:

1. Economic capital that can be associated with money or other ownership of objects, goods and the like that can be viewed and used for investment purposes,

2. Institutionalized cultural capital in the form of educational qualifications, and

3. Social capital which consists of social obligations in living together.

Coleman (1998) "social capital consists of several aspects of social structures, which facilitate certain actions for actors, both corporate actors and companies within the structure". Furthermore, Coleman in Santoso (2016) defines social capital as "an important resource for individuals and greatly influences their ability to act and the quality of life they feel". While Coleman in Mohan (2002) social capital has three forms: 
1. Obligations and expectations based on the trust worthiness of the social environment;

2. Information flow capacity of social structure;

3 . The norms are carried out with various sanctions.

Therefore, for Coleman, with the existence of trust in the social environment, the obligation will definitely be paid off. Coleman in Parwitaningsih (2010) says "social capital is weakened by processes that damage kinship, such as divorce, separation, or migration. When families leave their existing kinship networks, friends and other contacts, the value of their social capital falls."

Coleman and Bourdieu have similarities in the focus of the study, namely the individual, especially with regard to roles and relationships with others as a unit of analysis of social capital. Third; Putnam and Fukuyama theory. These two figures provide a definition of social capital which is closely related, especially regarding the concept of trust.

Putnam (1993) defines social capital as "a value of mutual trust (trust) between community members and the community towards their leaders". Social capital is defined as social institutions that involve networks, norms, and social trust that encourage social collaboration (coordination and cooperation) for the common good. This also implies that there is a need for social networks (networks of civic engagement), social ties/networks that exist in society, and norms that encourage community productivity.

Putnam provides a proposition that a community entity that has high social virtues, but lives socially isolated will be seen as a society that has a low level of social capital. In the same spirit, Fukuyama (1999) puts more emphasis on a broader dimension, namely social capital is "everything that makes people come together to achieve common goals on the basis of togetherness, and in which values and norms are bound to grow and obeyed.", ranging from reciprocal values between friends, to those that are very complex and contain religious values.

Fukuyama explains that "social capital is a set of informal values or norms that are shared among members of a community group that enable cooperation between them". In his view, Fukuyama views social capital as trust, namely the ability of people/societies to work together for a common goal (collective action) in groups or organizations. Referring to Fukuyama (1999), there are 3 (three) parameters of social capital, namely: (a) Trust; (b) Social network/Social; And (c) Social norms/Social norms.

Social capital has a very high influence on the development and progress of various economic sectors. Fukuyama (2002) shows the results of studies in various countries which show that strong social capital will stimulate the growth of various economic sectors because of the high level of trust and closeness of relationships in a wide growing network of fellow economic actors.

In his analysis, Fukuyama believes in religion as an abundant source of social capital. Religion has a role in rewarming social bonds and social control of society. Social capital which is embodied in religious values, is believed to be more effective and "cost" cheaper than any other institution. Harmony can only be achieved when members of the community are well connected with each other through networks and shared values that grow in society by prioritizing similarities rather than existing differences. These values are continuously maintained as a binding force, so that they become a separate force that is useful not only to achieve the shared goals that they aspire to, but also to fend off various efforts that threaten their cohesiveness.

Fourth; Other formulations of social capital theory were put forward by several figures including: Prusak in Barliana (2011) states that "social capital consists of trust, understanding, and the exchange of values and behaviors that build relationships between 
individuals and communities that allow mutually beneficial cooperation". Meanwhile, Narayan in Suharto (2007) states that social capital is the rules, norms, obligations, reciprocity and trust that binds in social relations, social structures and institutional arrangements of society that enable members to achieve target outcomes. individuals and their society.

\subsection{Development Theory}

Development is a systematic and continuous effort made to realize something that is aspired. Development is a change towards improvement. Changes towards improvement require the mobilization of all human resources and reason to realize what is aspired. In addition, development is also very dependent on the availability of natural resource wealth. The availability of natural resources is one of the keys to economic growth in an area. (Shah, M. et al. 2020)

The meaning of development in general is essentially a process of continuous change towards a better state based on certain norms. Regarding the definition of development, experts provide various definitions such as planning. The term development may be interpreted differently by one person to another, from one region to another, from one country to another. However, in general, there is an agreement that development is a process for making changes.

To explain community development as a phenomenon and a social reality, Soetomo (2012) is "Giving authority to the community to manage their own development process. The authority in question covers the whole process from identifying problems and needs, planning, implementing and evaluating. The following is the definition of development according to several experts. Todaro (2000) states "development is a multidimensional process that includes changes in social structures, public attitudes, national institutions, as well as increasing economic growth, reducing inequality and eradicating poverty".

According to Jayadinata (1999) that development is "to make or create or regulate something that does not yet exist". While development is advancing or improving or improving something that exists. These two terms are often used for different purposessame. Development and development is carried out for the prosperity and welfare of the community. Development and development (development) can be a physical development or physical development, and can be a socio-economic development and socio-economic development.

According Gant in Surtono (2001) there are two stages of development goals, the first stage, essentially development aims to eliminate poverty. If the results of this goal have begun to be felt, the second stage is to create opportunities for its citizens to be able to live happily and fulfill all their needs. To achieve the success of this development, there are many aspects or things that must be considered, including community involvement in development.

\section{Research Method}

In research studies, the use of methods is a step that must be taken so that problems can be answered objectively and thoroughly with the aim of being able to find, prove and develop knowledge, so that it can be used to understand, solve, and anticipate various problems. Considering the method is a procedure or method used to find out something by using systematic steps, then in every study, research methods must be used.

In accordance with the research objectives that have been set in the previous chapter, the research method used in this study is a qualitative method. Through the qualitative 
method, the researcher wants to gain an in-depth understanding and thought about social realities and facts that are relevant to the research objectives, of course related to development based on local wisdom in the research location.

In line with the above intention, Creswell (2010) stated that qualitative research is "methods for exploring and understanding the meaning that a number of individuals or groups of people consider to be derived from social or humanitarian problems". While Moleong (2014) argues that "qualitative research is based on efforts to build the views of those who are researched which are detailed, formed with words, holistic and complex pictures".

The method used in this research is a descriptive qualitative approach. That is, the qualitative method as a method and technique of study in which there is the use of propositions as a guide (guidelines) so that this research is more focused. Qualitative approach is characterized by research objectives that seek to understand the symptoms that do not require quantification or symptoms that are impossible to measure accurately. The qualitative approach used in this research is a case study. A case study is a research strategy in which the researcher carefully investigates a program, event, activity, process, or group of individuals (Creswell, 2010).

Sources of data in this study are all interested parties, while still referring to the problems to be studied. While the types of data collected in the form of primary data and secondary data. Determination of informants is doneby purposive, assuming that the informant understands the problem under study and can provide information on the problem that is the purpose of this research, taking into account their formal position and character in society.

The tools used in this research are non-participatory observation, in-depth interviews, namely interview guidelines as a source of primary data collection, and documentation studies. Meanwhile, to obtain secondary data by studying various literatures and official documents related to the problem under study. This technique was chosen to provide convenience in research activities, not intended to limit the level of flexibility of researchers as instruments in the field.

In general, there are three data collection techniques that researchers use, namely observation, in-depth interviews, and document studies. Efforts to collect data are flexible, according to the situation, conditions, and demands in the field, in this case, consistency and accuracy must be maintained so that the quality of the information obtained is maintained and meets standards and is objective.

According to Creswell (2010) observation is an activity "directly down to the field to observe the behavior and activities of individuals at the research location. In this observation, the researcher records / records both in a structured and semi-structured way. Bogdan in Moleong (2014) defines participatory observation as "research characterized by social interactions that take a long time between researchers and subjects in the subject's environment, during which time data in the form of field notes are collected systematically and applies without interruption.

According to Support in Bungin (2001) suggests eight things that researchers should pay attention to when conducting researchobservations include:

(1) Space and time;

(2) Perpetrator;

(3) Activity;

(4) Objects or tools;

(5) Time;

(6) Incident; 
(7) Purpose; and

(8) Feeling.

These eight things are interrelated so that the researchers' attention focuses on what is being observed. Observations involved not only done once or twice, but carried out intensively in an unlimited time.

In addition to observations, researchers also conducted interviews in order to collect data in the field, of course, related to the research focus that had been determined. With a simple concept Moleong (2014) interview is "a conversation with a specific purpose. The conversation was carried out by two parties, namely the interviewer (interviewer) who asked the question and the interviewee (interviewee) who gave the answer to the question.

After observation and interviews, the researcher also used documentation studies (document analysis) in this study as a complement to the two methods above. Documents are recordings of events that are closer to conversations, involve personal matters, and require interpretations that are closely related to the context of the recorded events. In this case,Mulyana (2013) these documents can reveal "How the subject defines himself, the environment and the situation he faces at a time, and how the relationship between that self-definition in relation to the people around him and his actions..

Documentation study is a data collection technique that is not directly addressed to the research subject. Documents under study can be in the form of various kinds, not only official documents. With the study of documentation, researchers seek information that occurs in society. The documents needed in this research are written materials related to the research title from various data sources that are useful for testing, interpreting and even predicting.

Document research techniques are used to obtain data related to relevant theories, such as development, as well as the concept of local wisdom and relevant previous research, as well as documents regarding development. The data that has been successfully collected through interviews and observations were then analyzed qualitatively. The data analysis was carried out continuously from the beginning during the research process.Based on that, then Data reduction, data presentation and verification/drawing conclusions. The results of the study are presented descriptively based on an understanding of the data or data phenomena and symptoms found.

Data analysis is also known as data processing and interpretation. After collecting field data, both primary and secondary data are classified according to the topics discussed and analyzed descriptively (descriptive analysis). This implies an attempt to simplify and at the same time explain parts of the overall data through the steps of classification and categorization as well as linking them to one another so that a systematic descriptive series can be arranged and can provide meaning from the aspects under study.

The data that the authors managed to collect from the field were then tabulated and analyzed descriptively qualitatively, then presented in a narrative form according to the problem being discussed. Data analysis is the process of processing research results, starting from compiling, grouping in similar categories, analyzing and interpreting data in patterns and relationships between concepts and formulating them in relationships between other elements so that they are easy to understand and understand. 


\section{Result and Discussion}

\subsection{Local Wisdom as Development Capital in Aceh Besar Regency}

Based on the results of the discussion related to capital in development, especially regarding mutual trust between residents with one another in the research location, it is still very strong. With high trust, it is easy for residents to provide assistance in carrying out development. This is due to several factors, firstly, many residents have lived in this area for a long time, more than twenty years, and secondly, many of the residents are still relatives or relatives. The characteristics of the community are still thick with spiritual life, a fairly high culture. Besides, in social life there is still a tradition of borrowing and borrowing in the form of money and basic necessities.

Community of Aceh Besar Regency it is still easy to be involved in various social activities, especially religious activities, the community will easily participate in these activities voluntarily. The level of togetherness and solidarity is very high, this also has an impact on mutual cooperation activities for cleaning or repairing public facilities, such as building roads, canals, sharpening and so on. In this case, citizen participation can be in the form of labor assistance, money, or other material donations that are used for common interests, for example to provide consumption during gotong royong activities.

Based on the description above, it means that there is a close relationship between local wisdom and the success of development in Aceh Besar Regency. The existence of mutual trust between citizens and the willingness to cooperate causes transaction costs to be lower, and the result is a more efficient and productive life. Thus, existing resources can be optimized to carry out activities that build added value for people's lives.

Local wisdom is very useful in the implementation of development that can generate high trust in the community. Second, there is a passion for charity (charity) in implementing the program. Third, there is a sense of volunteerism (volunteerism) that evokes self-reliance. Fourth, the existence of citizen involvement (civil involvement) or build participation. Fifth, strong sense of social solidarity and sixth, can maintain and build social integration in social life.

In every development sector, the factors of honesty, trust, openness, have a high level of empathy and become the basis that determines the development and sustainability of various business activities. The community in the research location has a good sense of tolerance in cultural life. Building tolerance by using a cultural systems approach in people's lives, guided by the values that apply to all members of a community. The stronger these values apply to groups in society, the morethe stronger the adhesive for them. This strong adhesive will strengthen the relationship between community members, so that cooperation and harmonious relationships are established.

The results show that tolerance is still strong, it can be seen from the attitude of mutual understanding in carrying out community activities, and tolerance is believed to be very important in order to achieve togetherness and a comfortable life. In building in Aceh Besar Regency, social norms are an important element of social capital apart from trust and social networks. Social norms consist of elements of shared values, norms and sanctions, and morality. Norms are a set of rules that are expected to be obeyed and followed by members of society in a certain group. These norms contain social sanctions that can prevent individuals from doing something that deviates from the prevailing habits in society.

Success creates a deal (consensus) regarding social norms and values as a guide in establishing interactions. Every social value and norm has been valid for quite a long time and has been implemented consistently as a guide and guide for every citizen in taking 
action. To achieve safe and peaceful life in social life, one must: (a) the creation of agreement from the majority of its members on certain fundamental and crucial social values (b) most of its members are gathered in various social units that supervise each other in potential social aspects. (c) The occurrence of interdependence among social groups that are gathered in meeting overall economic needs.

Social norms will play a role in controlling the forms of relationships between individuals in social life, if these rules are maintained properly it will have a positive impact on the quality of existing relationships and stimulate the continuity of a stronger social cohesiveness of life.

There are several values that are firmly held by society Aceh Besar Regency from ancient times to the present. These values are; first, the cultural value of deliberation in solving every problem, every decision concerning personal, family or community interests is always taken by means of deliberation. Deliberation has become a tradition in everyday life. Second, the cultural value of compassion, the value of love and affection for others, whether they are suffering or not. With this culture, it can provide convenience, especially for people who are experiencing a disaster.

This value can also describe the cultural value of being sensitive to others. And third, the cultural value of tolerance, tolerance and sympathy for fellow human beings, values and behavior towards fellow human beings, especially in a state of grief or disaster. This value tends to function as the glue of social bonds between human beings. Local wisdom owned by the community Aceh Besar Regency in this perspective is still strong, this is due to a strong social base, as well as the historical orientation and dimensions of the formation of values and norms in society due to the similarity of religion, profession, ideas/interests and kinship relations.

In connection with the above, in the implementation of development the values that are shared are still very strongly emphasized, among others, is speaking politely and respectfully to others in conducting deliberation in order to determine the priority scale of development programs Aceh Besar Regency. This trait creates the togetherness of the value of togetherness and feeling of interest.

\subsection{Forms of Local Wisdom}

One form of local wisdomal that is attached to the community at the research location is cooperation between residents or mutual assistance as the ability of community members to always unite themselves in a synergistic relationship pattern, will have a very large influence in determining whether or not the social capital is strong. And there is a strong desire from group members to not only cooperate, but find ways for their involvement in a community activity. In this view, the people of Aceh Besar it is still easy to invite them to cooperate in the construction/repair of roads, canals, Menasah, and mutual cooperation on clean Fridays.

The attitude of cooperation in the people of Aceh Besar Regency shows that it is still very strong. Cooperation in traditional relations, brotherly relations, friendship relations are very strong. All people are willing to participate in activities that benefit the community voluntarily. Generally, collective activities carried out are related to the implementation of religious activities (tahlilan, weddings, burials, recitations, mutual cooperation, or building other public facilities. Cooperation is largely determined by the personal awareness of residents. According to informants, all residents will be involved in development activities for the benefit of the community). Together. Likewise, if there are residents who get a disaster, most of the residents will help. Thus, in terms of collective action and cooperation, individual awareness is still relatively high, 
The human tendency to cooperate in various groups is not socially constructed or the product of rational choice. Cooperation starts from sociability which is learned from kinship, meaning that a process of cooperation with partnership is actually a pattern that has been studied in community kinship, workthat are built on mutual trust can provide benefits for both parties. The culture of a nation greatly determines the success of its human development. Development is notwill run smoothly without togetherness, closeness, mutual trust and the desire to learn and change for the better. In every development of a country, the social capital factor plays a very important role.

The results show that cooperation as an element of social capital in the implementation of development can increase development in three ways: (1) increasing individual cooperation in social networks so as to reduce transaction costs, in order to increase revenue, (2) increasing cooperation in local networks can reduce rent seeking behavior to facilitate collective action, and (3) network expansion and strengthening of social trust levels so that rural people have access to education, capital, and health services.

The cooperation that exists within the Aceh Besar Regency organization can be used as capital in gampong development, where members voluntarily give up some of their individual rights to work together to achieve a goal, based on agreed rules. The agreement causes everyone to carry out their respective obligations freely without the need for supervision, because each other believes that everyone will carry out their obligations.

In addition to collaboration, participation is also part of the form of local wisdom that is studied in this research. Community participation in development can realize a more prosperous region and community involvement in the implementation and management stages of the program has a positive impact on the progress of Aceh Besar Regency. The participation of the people of Aceh Besar Regency in development has received many benefits, namely in addition to increasing knowledge and skills in managing programs and implementing development, of course, as program actors, they also get to work hard to meet their needs. Community involvement in the implementation and management stages of the program has a positive impact in the long term. Community independence can be realized more quickly because the community is accustomed to managing development programs at the local level. In this case, the community felt valued through their involvement from the start.

Local wisdom in Aceh Besar Regency is the prevailing values in a society. Values that are believed to be true and become a reference in daily behavior for the local community. Therefore, it is reasonable to say that local wisdom is an entity that greatly determines human dignity in the community. This means that local wisdom contains elements of intelligence, creativity and local knowledge from the elite and the community who determine the development of civilization in their society.

The habits of deliberation in the life of the people of Aceh Besar Regency have a positive impact both in relation to general activities and individual activities, such as wedding parties so that they are facilitated by the existence of deliberation. The community provides social capital so that the budget for the owner of the need can be smaller than it should be. 


\section{Conclusion}

The local wisdom of capital owned by community members of Aceh Besar Regency in the implementation of development so as to increase trust and social norms is still strong enough to support the realization of development, and elements of social institutions are still quite strong in creating a conducive atmosphere in the community. The strength of local wisdom owned by the community Aceh Besar Regency This is caused by a strong social base, as well as the historical orientation and dimensions of the formation of values and norms, due to the similarity of religion and kinship relations.

Forms of local wisdom such as cooperation, participation which is used as a habit can generate high trust in the community, and a passion for charity (charity) in carrying out development and various community activities as well as a sense of volunteerism (volunteerism) that evokes self-reliance, citizen activity (civil involvement) or builds participation as well as a strong sense of social solidarity in Public.

\section{References}

Barliana, M. Syaom. (2011). Arsitektur, Ruang Publik, dan Pendidikan: Relasi Mutual untuk Penguatan Modal Sosial. Pidato Pengukuhan Guru Besar dalam bidang Sosiologi Arsitektur Pada Fakultas Pendidikan Teknologi dan Kejuruan. Bandung: Universitas Pendidikan Indonesia.

Bourdieu, Pierre. (1986). "The Forms of Capital” dalam John G. Richardson. Handbook of Theory and Research for the Sociology of Education. New York: Greenwood Press.

Creswell, John. W. (2010). Research Design. Diterjemahkan oleh. Fawaid, Achmad. Yogyakarta: Pustaka Pelajar.

Fukuyama, Francis. (1999). The End of History and The Last Man: Kemenangan Kapitalisme dan Demokrasi Liberal. Yogyakarta: Penerbit Qalam.

--. (2002). Trust: The Social Virtues and The Creation of Prosperity, diterjemahkan oleh Ruslani. Cetakan kedua. (2007). Yogyakarta: Qalam.

Garna, J.K. (1999). Metode Penelitian:Pendekatan Kualitatif. Bandung : CV Primaco Akademika.

Moleong, Lexy J. (2014). Metode Penelitian Kualitatif. Bandung: Remaja Rosdakarya.

Ngarawula, Bonaventura. (2012). Memahami Nasionalisme Masyarakat Lokal. Perspektif Sosiologi. Malang: Universitas Negeri Malang.

Peraturan Pemerintah Nomor 43 Tahun (2014). Tentang Peraturan Pelaksana UndangUndang Nomor 6 Tahun 1014 Tantang Desa.

Peraturan Pemerintah Nomor 47 Tahun (2015). Tentang Perubahan atas Peraturan Pemerintah Nomor 43 Tahun 2014. Tentang Peraturan Pelaksana Undang-Undang Nomor 6 Tahun 2014 Tantang Desa.

Purba, N. (2020). The Use of Simalungun Language by Anak Boru Sanina in the Simalungun Wedding Ceremony (Sociolinguistic Studies). Lakhomi Journal: Scientific Journal of Culture. 1-7

Shah, M. et al. (2020). The Development Impact of PT. Medco E \& P Malaka on Economic Aspects in East Aceh Regency. Budapest International Research and Critics Institute-Journal (BIRCI-Journal). P. 276-286.

Soetomo, (2012). Strategi-strategi Pembangunan Masyarakat. Yogyakarta: Pustaka Pelajar. Suharto, Edi. (2007). Modal Sosial dan Kebijakan Publik. pdf (secured). 23/6/2007. 1:49PM

Surtono, Agus. (2001). Teori dan isu Pembangunan. Malang: Universitas Malang Press. Todaro, P.M, Smith S.C. (2000). Pembangunan Ekonomi di Dunia Ketiga Jakarta: Erlangga. Undang-Undang Republik Indonesia Nomor 6 Tahun 2014. Tentang Desa. 